\title{
Gaseous Emission from the Combustion of Dual Purpose Kerosene (DPK) from the Kaduna Refinery and Petroleum Company in Nigeria
}

\author{
Oke Michael A, Oluwaseun Adedayo 0,* Oluwafumnmiso Ayodele I, Ademola Jacob S
}

Department of Chemical Engineering, Obafemi Awolowo University, Nigeria

\begin{abstract}
Kaduna Refinery and Petroleum Company convert crude oil and other liquids into refined petroleum products. These petroleum products are used in our various homes as a source of energy but they can be a threat to human lives and the ecosystem. Gaseous emissions from the combustion of DPK of different volumes from Kaduna Refining were characterized for gaseous air pollutants using the E8500 combustion analyzer. The concentrations for the gaseous emission from the combustion of DPK were $34.92 \mathrm{mg} / \mathrm{m}^{3} \mathrm{HC}, 21.67 \mathrm{mg} / \mathrm{m}^{3} \mathrm{CO}, 89.00 \mathrm{mg} / \mathrm{m}^{3} \mathrm{NO}_{\mathrm{x}}$ for $10 \mathrm{ml} .41 .47 \mathrm{mg} / \mathrm{m}^{3} \mathrm{HC}, 33.33 \mathrm{mg} /$ $\mathrm{m}^{3} \mathrm{CO}, 118.33 \mathrm{mg} / \mathrm{m}^{3} \mathrm{NO}_{x}$ for $20 \mathrm{ml} .52 .3 \mathrm{mg} / \mathrm{m}^{3} \mathrm{HC}, 49.33 \mathrm{mg} / \mathrm{m}^{3} \mathrm{CO}, 183.33 \mathrm{mg} / \mathrm{m}^{3} \mathrm{NO}_{\mathrm{x}}$ for $30 \mathrm{ml} .50 .20 \mathrm{mg} / \mathrm{m}^{3} \mathrm{HC}, 33.00 \mathrm{mg} / \mathrm{m}^{3} \mathrm{CO}, 189.33 \mathrm{mg} / \mathrm{m}^{3}$ $\mathrm{NO}_{\mathrm{x}}$ for $40 \mathrm{ml} .61 .12 \mathrm{mg} / \mathrm{m}^{3} \mathrm{HC}, 40.62 \mathrm{mg} / \mathrm{m}^{3} \mathrm{CO}, 199.00 \mathrm{mg} / \mathrm{m}^{3} \mathrm{NO}_{\mathrm{x}^{\prime}} 2.6 \mathrm{mg} / \mathrm{m}^{3} \mathrm{SO}_{2}$ for $50 \mathrm{ml}$. This study shows that CO and HC exceeded the acceptable limit for stationary sources while $\mathrm{NO}_{\mathrm{x}}$ and $\mathrm{SO}_{2}$ were below the acceptable limit. Hence, there is a need for rapid response and urgent attention from government and regulatory bodies to put in place policies that will help minimize the effect of these emissions.
\end{abstract}

Keywords: Refinery, Emissions, Concentration, Pollutants, Petroleum

\section{Introduction}

Air pollution is defined as the introduction of biological materials or chemicals into the surrounding air which can be harmful to humans, plants and structures. Air pollution is classified into anthropogenic and non-anthropogenic origins. Indoor and outdoor air pollution have been a major concern in both developed and less developed nations. Any substance that contaminates air quality is termed air pollutant. Air pollution is basically the presence of air pollutants such as sulphur dioxide $\left(\mathrm{SO}_{2}\right)$, particle substances (PM), nitrogen oxides $\left(\mathrm{NO}_{\mathrm{x}}\right)$ and ozone $\left(\mathrm{O}_{3}\right)$ in the air that when ingested at levels, brings about adverse effects on human health and the environment. Ogwu et al. ${ }^{1}$ highlighted important criteria air pollutants that contribute to ambient air pollution which may include sulphur dioxide $\left(\mathrm{SO}_{2}\right)$, carbon monoxide (CO), oxides of nitrogen ( $\left.\mathrm{NO}_{\mathrm{x}}\right)$, ozone $\left(\mathrm{O}_{3}\right)$, total suspended particulate matter (TSP) and lead $(\mathrm{Pb})$. These pollutants increasingly pose both direct and indirect risks to human health, structures of the society and atmospheric visibility in the environment. Maintaining standard air quality limits has become a significant task for policymakers as well as for non-governmental organizations. The industrial and commercial use of refined petroleum products has brought about immense growth and development in the country. The process of technology in the advancement of industrialization often resulted in unacceptable levels of toxic and effluent emissions. These culminated in air pollutants emissions and the degradation of the atmosphere and environment in general. Many environmental laws have been enacted with the aim of changing the makeup of refined petroleum effluents so that they can produce fewer and environmentally friendly emissions ${ }^{2}$ but there are limited scientific efforts to establish if these laws are complied with.

The dependence on refined petroleum products in the country cannot be over-emphasized. Significant sectors contributing to atmospheric degradation are power generation, vehicular transport.

\begin{tabular}{|l|l|}
\hline \hline Quick Response Code: & $\begin{array}{l}\text { *Corresponding author: Osunnusi Oluwaseun Adedayo, Environmental Engineering Re- } \\
\text { search Laboratory, Department of Chemical Engineering, Obafemi Awolowo University, Ile-Ife, } \\
\text { Nigeria. } \\
\text { Received: 07 January, } 2021 \\
\text { Citation: Oke MA, Oluwaseun AO, Oluwafumnmiso AI, Ademola JS. Gaseous Emission from the } \\
\text { Combustion of Dual Purpose Kerosene (DPK) from the Kaduna Refinery and Petroleum Com- } \\
\text { pany in Nigeria. Trends Petro Eng. 2021;1(1):1-4. DOI: 10.53902/TPE.2021.01.000502 }\end{array}$ \\
\hline
\end{tabular}


incineration, biomass and waste burning using combustion of refined petroleum products. Due to this dependence, it is expedient to measure and characterize these emissions coming from the combustion of these products. Combustion of petroleum products during power generation, vehicular activities and industrial activities as in construction and production is termed the major source of air pollutants emission into the ambient and outdoor environment. Kaduna Refining and Petrochemical Company (KRPC) has been continuously releasing and producing refined petroleum products into the country for about 40 years. Combustion of these refined products is said to pose a serious risk to human health when admitted into the body system via respiring on the pollutants emitted. Combustion of these refined products produce emissions which include carbon monoxide (CO), carbon dioxide $\left(\mathrm{CO}_{2}\right)$, sulphur dioxide $\left(\mathrm{SO}_{2}\right)$, oxides of nitrogen $\left(\mathrm{NO}_{\mathrm{x}}\right)$, ) and hydrocarbons (HCs). The dependence on refined petroleum products in the country cannot be over-emphasized. Significant sectors contributing to atmospheric degradation are power generation, vehicular transport. incineration, biomass and waste burning using combustion of refined petroleum products. Due to this dependence, it is expedient to measure and characterize these emissions coming from the combustion of these products.

The products released from the combustion of KRPC refined petroleum products may include criteria air pollutants but these have not been scientifically quantified. The consumption of these refined products through combustion activities such as vehicular emissions, industrial activities among others may have adverse effects ranging from short term to long term health issues if not managed effectively. Anthropogenic effects from the combustion of refined products can be traced to various terminal health issues, it is, therefore, essential to investigate the air quality impacts associated with the combustion of refined products and to verify its level of compliance with emission limits adopted in the country.

\section{Materials and Methods}

The materials and equipment used during the combustion of KRPC refined petroleum products include Fuel samples-gasoline, kerosene and diesel; measuring cylinder; conical flask; a combustion chamber; an air compressor; a combustion analyser.

Figure 1 shows the map of the study area.

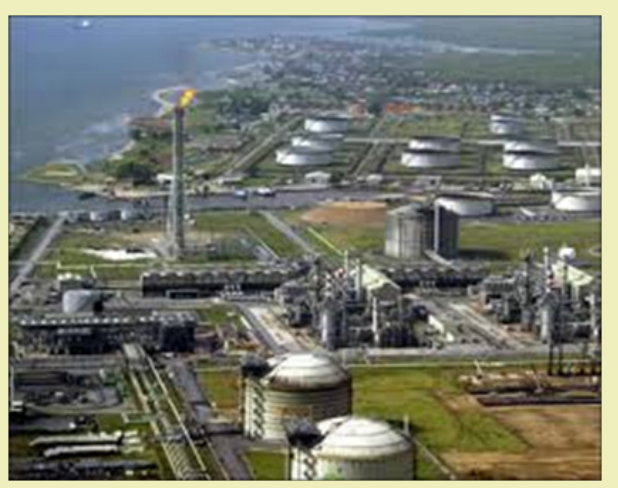

Figure 1: Kaduna Refining and Petroleum Company.

\section{Combustion apparatus, fuel and experimental proce- dure}

The E8500 plus combustion analyser (Figure 2) was used for gaseous emission characterization. It is the most powerful and advanced portable emissions analyser on the market and is a complete, portable tool for EPA compliance-level emissions monitoring of boilers, engines, and other combustion equipment. It has up to nine gas sensors with a weight of $5 \mathrm{~kg}$ and a dimension of $26 \times 15 \times 24$ $\mathrm{cm}$.

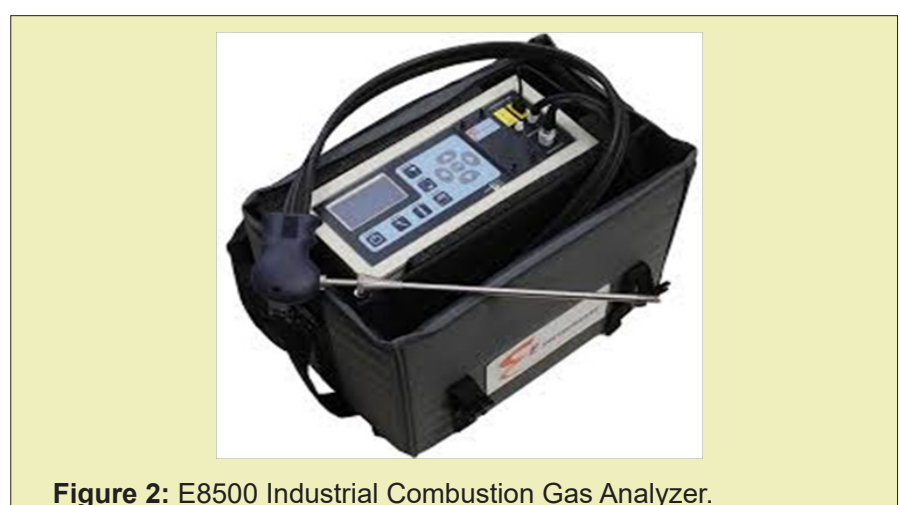

Figure 2: E8500 Industrial Combustion Gas Analyzer.

It is an analyser equipped with inbuilt thermoelectric chiller which efficiently and quickly removes watervapour from gas samples to prevent gases from bubbling into the condensate drain gas velocity measurement capability which makes the instrument scientifically efficient. Gaseous emissions from the combustion of refined petroleum products were measured using the E8500 plus portable industrial gas and emissions analyser. The combustion analyser is capable of measuring gaseous emissions including; $\mathrm{Ox}-$ ygen $\left(\mathrm{O}_{2}\right)$, Hydrocarbons ( $\left.\mathrm{HC}\right)$, carbon monoxide (CO), carbon dioxide $\left(\mathrm{CO}_{2}\right)$, Oxides of Nitrogen $\mathrm{NO}_{\mathrm{x}}\left(\mathrm{NO}, \mathrm{NO}_{2}\right)$, Sulphur dioxide $\left(\mathrm{SO}_{2}\right)$, and Hydrogen Sulphide $\left(\mathrm{H}_{2} \mathrm{~S}\right)$. Its $\mathrm{CO}$ detection range is $0-2000 \mathrm{ppm}$ with 1 ppm resolution while its $\mathrm{NO}$ and $\mathrm{NO}_{2}$ detection range is $0-400 \mathrm{ppm}$ with $1 \mathrm{ppm}$ resolution. The detection range of its $\mathrm{H}_{2} \mathrm{~S}$ is $0-500 \mathrm{ppm}$ with $1 \mathrm{ppm}$ resolution. In addition, the temperature of the flue gas and the ambient air in its area of operation can also be measured with the analyser at the range of $0-1000^{\circ} \mathrm{C}$. It also measures pressure/draft excess air of combustion, gas velocity, and the efficiency of combustion.

The air compressor used is a 50-litre air receiver which has a 3 HP, 230 V, 1 HP motor with electrical overload protection. This 66 kg robust air compressor of 930x420x800mm dimensions features a heavy-duty cast iron pump, designed to appeal to commercial, agricultural, and consumer users. It delivers a more-than-adequate volume \& pressure of compressed air. It has also a maximum working pressure of $10.3 \mathrm{bar}$ (148.5psi) controlled by a fully automatic pressure switch. It has a cast-iron ' $V$ ' type twin cylinder air compressor pump with $15 \mathrm{cfm}$ displacement. The air compressor is powered by a petrol-fuelled engine which is placed far away from the combustion chamber and analyser so that it does not influence the emissions being read by the analyser. It is capable of providing a more than adequate volume and pressure of compressed air to 
power professional spray-guns and many of the frequently used air tools.

Without the gas sampling probe connected to the instrument, the combustion analyser is turned on. Baseline calibration is required to zero out any sensors that may have drifted far of zero. After the required baseline calibration and there were no errors, the gas sampling probe is connected to the instrument. The electronic analyser is now ready for use to monitor any gaseous emission for which the appropriate sensor is installed. Gaseous emissions including; Hydrocarbons (HC), carbon monoxide (CO), carbon dioxide $\left(\mathrm{CO}_{2}\right)$, Oxides of Nitrogen ( $\left.\mathrm{NO}, \mathrm{NO}_{2}, \mathrm{NOx}\right)$, Sulphur dioxide $\left(\mathrm{SO}_{2}\right)$, and Hydrogen Sulphide $\left(\mathrm{H}_{2} \mathrm{~S}\right)$ were measured with the use of the combustion analyzer. All emissions were measured in $\mathrm{mg} / \mathrm{m}^{3}$ with the exception of $\mathrm{HC}$ and $\mathrm{CO}$ which was measured in ppm and \% respectively. Fuel samples were stored in air-tight plastic containers to avoid contamination and maintain sample quality. The fuel containers were leak-proof to prevent the escape of gases including hydrocarbon. The fuel samples stored was DPK from KRPC. The volume of DPK was varied between $10 \mathrm{ml}$ and $50 \mathrm{ml}$. This was done to determine the time taken for each volume to be combusted and characterization of the air pollutants. Also, to determine the emission rate of the gaseous pollutant which is the unit mass of gaseous emissions per time taken for characterization of the air pollutants from the combustion of KRPC refined petroleum products. For each experimental run, a varied volume of refined products was measured with a measuring cylinder.

\section{Sampling and measurement techniques}

Air was passed into the combustion chamber with the aid of a Clarke air CE compressor (Figure 3) to provide sufficient air for the combustion process. The air supplied was at a constant flowrate which was achieved at the maximum working pressure condition of the compressor, 10.3bar (148.5psi). The air compressor was powered by a petrol-fuelled engine which was placed far away from the combustion chamber and analyser so that the compressor emissions do not interfere with the emissions being read by the analyser.

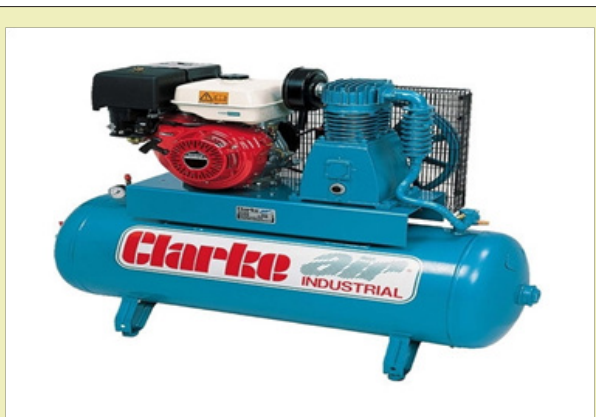

Figure 3: Clarke Air CE Compressor.

For each experimental run, the measured volume sample of each DPK was transferred into the combustion chamber, air from the compressor was passed into the chamber and ignition was done via the ignition hole using a lightning gun. The lid was placed firmly on it as combustion commences. During the combustion process, gaseous emissions including; Hydrocarbons (HC), carbon monox- ide (CO), carbon dioxide $\left(\mathrm{CO}_{2}\right)$, Oxides of Nitrogen ( $\mathrm{NO}, \mathrm{NO}_{2}, \mathrm{NO}_{\mathrm{x}}$ ), Sulphur dioxide $\left(\mathrm{SO}_{2}\right)$, and Hydrogen Sulphide $\left(\mathrm{H}_{2} \mathrm{~S}\right)$ were emitted into the atmosphere from the combustion chamber stack and into the atmosphere. The combustion analyser gas probe was inserted into the combustion zone through the stack of the chamber in order to measure the accurate air pollutants coming directly from the combustion zone in the chamber as opposed the ambient zone when measured from the top of the combustion chamber.

Readings were taken and recorded with the use of the combustion analyzer as the concentration values of air pollutants changed during the period of combustion. At the end of combustion, the combustion analyzer was calibrated back to zero in order to zero out the sensors that may have drifted far of zero. Three experimental runs were carried out for each volume of refined products that were varied.

\section{Results and Discussion}

For the varied volume of DPK experiment carried out in the laboratory, the average measured gaseous emissions and time taken during combustion of DPK are presented below. The statistical descriptions of the emissions from the DPK combustion can be seen in Figure 4. The measured average concentrations for the combustion of $10 \mathrm{ml}$ of DPK were $34.923 \mathrm{mg} / \mathrm{m}^{3}$ of $\mathrm{HC}, 21.667 \mathrm{mg} /$ $\mathrm{m}^{3}$ of $\mathrm{CO}, 89 \mathrm{mg} / \mathrm{m}^{3}$ of $\mathrm{NO}_{\mathrm{x}}$ and zero values were recorded for $\mathrm{CO}_{2}$ and $\mathrm{SO}_{2}$. For $20 \mathrm{ml}$ of DPK, the measured average concentrations were $41.471 \mathrm{mg} / \mathrm{m}^{3}$ of $\mathrm{HC}, 33.333 \mathrm{mg} / \mathrm{m}^{3}$ of $\mathrm{CO}, 118.333 \mathrm{mg} / \mathrm{m}^{3}$ of $\mathrm{NO}_{\mathrm{x}}$ and zero values were recorded for $\mathrm{CO}_{2}$ and $\mathrm{SO}_{2}$. For $30 \mathrm{ml}$ of DPK, the measured average concentrations were $52.385 \mathrm{mg} / \mathrm{m}^{3}$ of $\mathrm{HC}, 49.333 \mathrm{mg} / \mathrm{m}^{3}$ of $\mathrm{CO}, 183.333 \mathrm{mg} / \mathrm{m}^{3}$ of $\mathrm{NO}_{\mathrm{x}}$ and zero values were recorded for $\mathrm{CO}_{2}$ and $\mathrm{SO}_{2}$. For $40 \mathrm{ml}$ of DPK, the measured average concentrations were $50.202 \mathrm{mg} / \mathrm{m}^{3}$ of $\mathrm{HC}, 33 \mathrm{mg} / \mathrm{m}^{3}$ of $\mathrm{CO}$, $189.333 \mathrm{mg} / \mathrm{m}^{3}$ of $\mathrm{NO}_{x^{\prime}} 3 \mathrm{mg} / \mathrm{m}^{3}$ of $\mathrm{SO}_{2}$ and $0 \mathrm{mg} / \mathrm{m}^{3}$ of $\mathrm{CO}_{2}$. For 50 $\mathrm{ml}$ of DPK, the measured average concentrations were $61.115 \mathrm{mg} /$ $\mathrm{m}^{3}$ of $\mathrm{HC}, 40.667 \mathrm{mg} / \mathrm{m}^{3}$ of $\mathrm{CO}, 191 \mathrm{mg} / \mathrm{m}^{3}$ of $\mathrm{NO}_{x^{\prime}}, 2.667 \mathrm{mg} / \mathrm{m}^{3}$ of $\mathrm{SO}_{2}$ and $0 \mathrm{mg} / \mathrm{m}^{3}$ of $\mathrm{CO}_{2}$. The measured concentration of gaseous pollutants for $10 \mathrm{ml}$ of DPK for the three (3) experimental runs were in the range of $26.192-39.288 \mathrm{mg} / \mathrm{m}^{3}$ for $\mathrm{HC}, 21-26 \mathrm{mg} / \mathrm{m}^{3}$ for $\mathrm{CO}, 42-186 \mathrm{mg} / \mathrm{m}^{3}$ for $\mathrm{NO}_{x^{\prime}} 0 \mathrm{mg} / \mathrm{m}^{3}$ for $\mathrm{SO}_{2}$ and $0 \mathrm{mg} / \mathrm{m}^{3}$ for $\mathrm{CO}_{2}$, the mean and standard deviation were $34.9236 .174,21.6673 .3,89$ 68.6 for $\mathrm{HC}, \mathrm{CO}$ and $\mathrm{NO}_{\mathrm{x}}$ respectively.

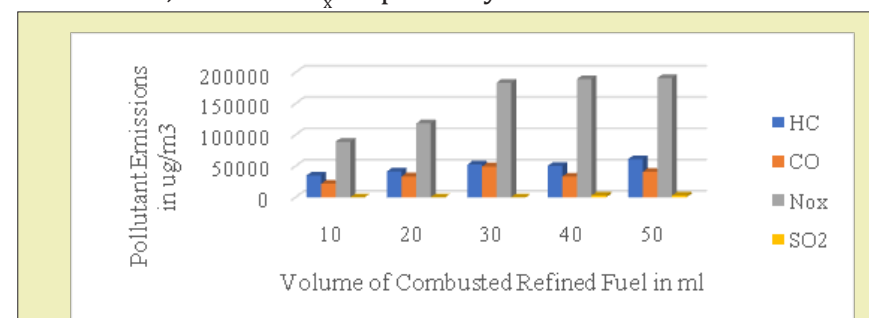

Figure 4: Descriptive Statistic of Gaseous Emissions from the Combustion of Varying Volumes of DPK.

The measured concentration of gaseous pollutants for $20 \mathrm{ml}$ of DPK for the three (3) experimental runs were in the range of $39.288-45.836 \mathrm{mg} / \mathrm{m}^{3}$ for $\mathrm{HC}, 0-50 \mathrm{mg} / \mathrm{m}^{3}$ for $\mathrm{CO}, 84-137 \mathrm{mg} / \mathrm{m}^{3}$ for $\mathrm{NO}_{x^{\prime}} 0 \mathrm{mg} / \mathrm{m}^{3}$ for $\mathrm{SO}_{2}$ and $0 \mathrm{mg} / \mathrm{m}^{3}$ for $\mathrm{CO}_{2}$, the mean and standard deviation were $41.471 \pm 3.087,33.333 \pm 23.6,118.333 \pm 24.3$ for 
$\mathrm{HC}, \mathrm{CO}$ and $\mathrm{NO}_{\mathrm{x}}$ respectively. The measured concentration of gaseous pollutants for $30 \mathrm{ml}$ of DPK for the three (3) experimental runs were in the range of $45.836-65.781 \mathrm{mg} / \mathrm{m}^{3}$ for $\mathrm{HC}, 49-49 \mathrm{mg} / \mathrm{m}^{3}$ for $\mathrm{CO}, 156-196 \mathrm{mg} / \mathrm{m}^{3}$ for $\mathrm{NO}_{x^{\prime}} 0 \mathrm{mg} / \mathrm{m}^{3}$ for $\mathrm{SO}_{2}$ and $0 \mathrm{mg} / \mathrm{m}^{3}$ for $\mathrm{CO}_{2}$, the mean and standard deviation were $52.385 \pm 9.26,49.33 \pm 0.5$, $183.333 \pm 19.3$ for $\mathrm{HC}, \mathrm{CO}$ and $\mathrm{NO}_{\mathrm{x}}$ respectively.

The measured concentration of gaseous pollutants for $40 \mathrm{ml}$ of DPK for the three (3) experimental runs were in the range of $45.836-65.480 \mathrm{mg} / \mathrm{m}^{3}$ for $\mathrm{HC}, 15-42 \mathrm{mg} / \mathrm{m}^{3}$ for $\mathrm{CO}, 244-248 \mathrm{mg} / \mathrm{m}^{3}$ for $\mathrm{NO}_{\mathrm{x}}$ and $3-3 \mathrm{mg} / \mathrm{m}^{3}$ for $\mathrm{SO}_{2}, 0 \mathrm{mg} / \mathrm{m}^{3}$ for $\mathrm{CO}_{2}$, the mean and standard deviation were $50.201 \pm 11.13,33 \pm 12.7,189.333 \pm 80.2,3 \pm 0$ for $\mathrm{HC}, \mathrm{CO}, \mathrm{NO}_{\mathrm{x}}$, and $\mathrm{SO}_{2}$ respectively. The measured concentration of gaseous pollutants for $50 \mathrm{ml}$ of DPK for the three (3) experimental runs were in the range of $52.385-65.481 \mathrm{mg} / \mathrm{m}^{3}$ for $\mathrm{HC}, 26-49 \mathrm{mg} /$ $\mathrm{m}_{3}$ for $\mathrm{CO}, 125-233 \mathrm{mg} / \mathrm{m}^{3}$ for $\mathrm{NO}_{\mathrm{x}^{\prime}}, 2-3 \mathrm{mg} / \mathrm{m}^{3}$ for $\mathrm{SO}_{2}$ and $0 \mathrm{mg} /$ $\mathrm{m}^{3}$ for $\mathrm{CO}_{2}$, the mean and standard deviation were $61.115 \pm 6.174$, $40.667 \pm 10.4,191 \pm 47.2,2.667 \pm 0.47$, for $\mathrm{HC}, \mathrm{CO}, \mathrm{NO}_{\mathrm{x}^{\prime}}$ and $\mathrm{SO}_{2}$ respectively.

Emissions of $\mathrm{NO}_{\mathrm{x}}$ result from high-temperature combustion of fuel for industrial activities and residential heating, and vehicle use. ${ }^{3}$ The three main reasons for $\mathrm{NO}_{\mathrm{x}}$ formation during fuel combustion are: thermal $\mathrm{NO}_{\mathrm{x}}$ (formed from atmospheric nitrogen above $1300^{\circ} \mathrm{C}$ ), prompt $\mathrm{NO}_{\mathrm{x}}$ formed at the flame front and fuel-No formed from elemental nitrogen contents of the fuel. ${ }^{4,5}$ also the emission of $\mathrm{SO}_{2}$ varied insignificantly between the different refined products. ${ }^{6}$ This study opined that the emissions vary as a function of fuel bound sulphur content present in the refined product. Emissions of $\mathrm{HC}$ are produced during combustion and their rate of production is affected by time in the combustion chamber, fuel and air mix, temperature, turbulence, pressure and design of chamber. ${ }^{7}$

Table 1: Emission Limits for Specific Pollutants from Stationary Source.

\begin{tabular}{|c|c|}
\hline Pollutant & Limits $\left(\mathbf{m g} / \mathbf{m}^{3}\right)$ \\
\hline Carbon monoxide & 10 \\
\hline Hydrocarbon & 50 \\
\hline Oxides of Nitrogen & $350-1000$ \\
\hline Sulphur dioxide & $30-3000$ \\
\hline
\end{tabular}

Source: (FMEnv, 1991)

When the emissions of DPK combustion from varying volume (10ml-50ml) (Table 1) are compared withlimits for gaseous emissions from stationary sources in Table 1, HC emitted from DPK combustion were below the acceptable emission limit for stationary sources excluding both $30 \mathrm{ml}$ and $50 \mathrm{ml}$, while the average emissions of HC were below the acceptable limit. CO emitted from DPK combustion breached the acceptable emission limit for stationary sources. For $\mathrm{NO}_{x}\left(\mathrm{NO}\right.$ and $\mathrm{NO}_{2}$ ), it was observed that its emission from DPK combustion was below the acceptable limits for stationary sources. Also, it was observed that the emissions of $\mathrm{SO}_{2}$ were below both the lower and the upper set limits. Deduced from the comparison, emissions from DPK combustion were below the set standards acceptable for stationary source except for carbon monoxide emission. Hence, DPK from KRPC could serve as a source of energy with sustainable environmental effects. ${ }^{9}$

\section{Conclusion}

This study identifies air pollutants related to the combustion of DPK. Dual-Purpose Kerosene (DPK) was combusted in an experimental chamber. Air pollutants such as Hydrocarbons (HCs), Carbon Monoxide (CO), oxides of Nitrogen $\left(\mathrm{NO}_{\mathrm{x}}\right)$, Sulphur dioxide $\left(\mathrm{SO}_{2}\right)$ and Carbon dioxide $\left(\mathrm{CO}_{2}\right)$ were characterized with the use of a combustion gas analyser and these pollutants when released into the environmentaffects the air quality of the study area. The cumulative effects of these air emissions continue to result in the poor air quality of the study area which poses a great health risk for the citizens. Therefore government and regulatory bodies should rise up to the task of reducing these emissions to the acceptable level because there is no doubt that this scenario has continued to lead to environmental hazards, loss and damage of lives and properties.

\section{Acknowledgments}

None.

\section{Conflicts of Interest}

Authors declares that there is no conflict of interest.

\section{Funding}

None.

\section{References}

1. Ogwu FA, Ajayi AP, Hussaini BA, et al. An Investigative Approach on the Effect of Air Pollution on Climate Change and Human Health in The Niger Delta Region of Nigeria. International Journal of Scientific Research and Innovative Technology. 2015;2(5):37-49.

2. USDE. Environmental benefits of advanced oil and gas exploration and production technology. 1999.

3. Bhawna D, Shivangi S, Reni D. Air Pollutants and their Environmental Impact: A Review. International Journal of Advanced Research in Engineering and Applied Sciences. 2013;2(5):34-38.

4. Werther J, Saenger M, Hartge EU, et al. Combustion of Agricultural Residues. Progress in Energy Combustion Science. 2000;26(1):1-27.

5. Habi MA, Elshafei M, Dajani M. Influence of Combustion Parameters on NOxProduction in an Industrial Boiler. Computers and Fluid. 2008;37(12):12-23.

6. Alen R, Kuoppala E, Oesch P. Formation of the Main Degradation Compound Groups from Wood and its Components during Pyrolysis. Journal of Analytical and Applied Pyrolysis.1996;36(2):137-148.

7. Kumar A. Introduction to Air Pollution. Columbia: University of Toledo; 2010.

8. FMEnv. Guidelines and Standards for Environmental Pollution Control in Nigeria. 1991.

9. Ghorani-Azam A, Riahi-Zanjani B, Balali-Mood M. Effects of air pollution on human health and practical measures for prevention in Iran. J Res Med Sci. 2016;21:65. 